УДК 316.614-057.36

л. І. Мульована, ст. викладач, Т. С. Острянко, к. пед. н.

\title{
АНАЛІЗ РЕЗУЛЬТАТІВ ЕМПІРИЧНОГО ДОСЛІДЖЕННЯ БАЗОВИХ ПЕРЕКОНАНЬ УЧАСНИКІВ АНТИТЕРОРИСТИЧНОЇ ОПЕРАЦІЇ
}

Актуальність теми дослідження. Психосоціальна підтримка та реабілітація учасників АТО вкрай важлива. Участь у бойових діях змінює особистість: відбувається зміна світогляду; базові переконання набувають якісно нового значення.

Постановка проблем. Війна на Сході України зумовлює потребу в розвитку соціальних послуг, удосконаленні реабілітаційних заходів та соціальній адаптації учасників АТО. Ця проблема потребує ірунтовного наукового дослідження та систематизації знань про соціальнопсихологічні особливості учасників АTO.

Аналіз останніх досліджень і публікацій. Дослідженням базових переконань особистості присвячені праці вчених: A. Beck, M. Dutton, S. Epstein, E. K. Fletcher, R. Janoff Bulman, F. H. Norris, М. А. Падун, Н. В. Тарабрина.

Виділення недосліджених частин загальної проблеми. Малодослідженими залишаються теоретичні та практичні аспекти змін у структурі особистості, в тому числі і базові переконання учасників АТО.

Постановка завдання полягає у висвітленні результатів емпіричного дослідження базових переконань учасників АTO.

Виклад основного матеріалу. Наводимо результати дослідження базових переконань. «Доброзичливість оточуючого світу» знаходиться у середніх показниках у $88 \%$ учасників АТО та 90\% контрольної групи. Високі показники «Справедливість» у 64\% учасників АTO та 46,6\% контрольної групи. «Образ Я» на високому рівні у 57\% учасників АТО та 40\% контрольної групи. Високі показники «Вдача» у 51\% учасників АТО та 43,3\% контрольної групи. У $61 \%$ учасників ATO та 30\% контрольної групи «Переконання про контроль» мають високі значення.

Висновки. Отже, бойовий досвід в переважної частини учасників АТО носить конструктивний характер. Це проявляється в усвідомленні сили власного Я, підвищенні цінності самого життя та знаходженні можливостей для самореалізації.

Розвиток соціально-психологічних послуг для учасників АТО має відбуватися через наснаження, фрормування віри у власні можливості.

Ключові слова: учасники антитерористичної операції; базові переконання; доброзичливість оточуючого світ;справедливість; образ Я; вдача; переконання про контроль.

\section{I. Muliovana, Senior Lecturer, \\ T. S. Ostrianko, Candidate of Pedagogical Sciences}

\section{ANALYSIS OF THE RESULTS OF EMPIRICAL RESEARCH OF THE BASIC BELIEFS OF THE PARTICIPANTS OF THE ANTITERRORIST OPERATION}

Urgency of the research. Psychosocial support and rehabilitation of ATO participants is very important. Participation in combat changes personality: there is a change in world outlook; basic beliefs acquire a qualitatively new meaning.

Target setting. There is a need for development of social services, improvement of rehabilitation measures and social adaptation of ATO participants. Needed solid scientific research and systematization of knowledge about the socio-psychological peculiarities of ATO participants.

Actual scientific researches and issues analysis. The research of the basic beliefs of the individual is devoted to the work of scientists: A. Beck, M. Dutton, S. Epstein, E. K. Fletcher, R. Janoff Bulman, F. H. Norris, M. A. Padun, N. V. Tarabrina.

Uninvestigated parts of general matters defining. Theoretical and practical aspects of changes in the structure of the person, including the basic beliefs of the participants of the ATO, are still poorly 
researched.

The research objective is to highlight the results of an empirical study of the basic beliefs of ATO participants.

The statement of basic materials. Here are the results of the study of basic beliefs. "Benevolence of the surrounding world" is in the average figures in $88 \%$ of ATO participants and $90 \%$ of the control group. High "Fairness" indicators in 64\% of ATO participants and $46.6 \%$ of the control group. "Image of I" is high at $57 \%$ of ATO participants and $40 \%$ of the control group. $51 \%$ of the ATO participants and $43.3 \%$ of the control group have high rates of "Luck". $61 \%$ of ATO and $30 \%$ of the "Belief in control" have high significance.

Conclusions. Combat experience in most ATO participants is constructive. This manifests itself in the awareness of the power of my own self, increasing the value of life itself and finding opportunities for self-realization.

The development of social and psychological services for ATO participants should take place through inspiration, the formation of faith in their own capabilities.

Keywords: participants in the anti-terrorist operation, basic beliefs, benevolence of the surrounding world, justice, the image I, luck, belief in control.

$$
\text { DOI: 10.25140/2412-1185-2019-1(13)-65-70 }
$$

Актуальність теми дослідження. Розв'язання проблем психосоціальної підтримки та реабілітації учасників антитерористичної операції в останні роки набуває все більшого значення. У ветеранів, під впливом психотравмуючого досвіду участі у військових подіях, відбувається зміна світогляду, уявлення про навколишній світ та самих себе набувають якісно нового значення. Відтак, особливого значення набуває система базових переконань, яка уможливлює ефрективну інтеграцію ветеранів до мирного життя.

Постановка проблеми. Військові події на Сході України зумовлюють потребу в розвитку соціальних послуг, удосконаленні реабілітаційних заходів та соціальній адаптації осіб, що постраждали від війни.

Одним із пріоритетних напрямків політики держави є соціальна інтеграція учасників бойових дій в суспільство. Багатовимірність даної проблеми потребує ґрунтовного наукового дослідження та систематизації знань про соціально-психологічні особливості цієї категорії осіб.

Станом на 1 червня 2019 року за інформацією, що надійшла від відомчих комісій щодо надання статусу учасника бойових дій особам, які брали участь у проведенні антитерористичної операції, статус учасника бойових дій надано 369294 особам [1]. Слід відмітити, що травмуючі події впливають не лише на учасника війни, а і на його оточення, в першу чергу, родину. Тому, проблеми психологічного та емоційного відновлення, адаптації, пошуку особистісних та соціальних ресурсів, набувають актуальності.

Участь у військових подіях змінюе систему уявлень особистості про світ та про себе. Американський психолог Ронні Янов-Бульман [6] описує модель психічної травми як пошкодження структури базових переконань. В міжособистісній взаємодії особа структурує свій досвід, фрормулює та реструктурує імпліцитну картину світу, що включають переконання про власну цінність, доброзичливість та справедливість світу. Травматичні події руйнує наступні базові переконання:

1) Переконання про доброзичливість оточуючого світу. Доброзичливий образ світу та довіра оточуючим є запорукою життєздатності людини, ії готовності вступати в соціальну взаємодію. Базова довіра світу може похитнутись в результаті впливу травматичних подій, які руйнують значимі зв'язки та фрагментують особистий досвід.

2) Переконання про справедливість оточуючого світу. Надзвичайно важлива та універсальна потреба людини - вірити в те, що в нашому світі кожна людина отримує по заслугам, погана поведінка карається, а гарна винагороджується. Уявлення про справедливість дозволяє людям дотримуватись культурних норм та приписів, здійснювати саморегуляцію в міжособистісній та соціальній взаємодії заради досягнення більшої вигоди та мінімізації можливих втрат, підтримувати власну самооцінку та поділяти групові цінності. Травматична подія руйнівним чином впливає на уявлення про справедливість світу. Люди по різному приборкують тривогу, що виникає через втрату віри у справедливий світ. Травматична подія ставить постраждалих та 
оточуючих перед когнітивним дисонансом між вірою в справедливий світ та фрактом несправедливих подій.

3) Переконання про цінність власного Я. Сюди входять три компоненти, що складають суб'єктивне благополуччя особистості: позитивний образ - Я (самооцінка), відчуття контролю (саморегуляція), відчуття власної цінності та значимості (самовідношення). В свою чергу, самооцінка складається з трьох соціально-психологічних компонентів - самоповаги, соціальної довірливості та здатності до навчання, та двох фрізичних компонентів - зовнішнього виду та фізичних можливостей. В першу чергу травматична подія ставить під сумнів уявлення людини про свою здатність до контролю. Намагаючись впоратись з негативними емоційними наслідками травматичної події та запобігти відчуття безпорадності та вразливості, люди схильні звинувачувати себе в тому, що сталось. Намагаючись ретроспективно відновити відчуття контролю, люди нав'язливо повертаються думками до того, що було б, якщо б вони повели себе по іншому. Травматичний досвід доволі часто призводить до того, що спроби захистити та зберегти від руйнування необхідні для суб'єктивного благополуччя базові переконання про світ та самого себе призводять до самозвинувачення та само знецінення, що підсилює симптоми посттравматичного стресу.

Конфронтація базових переконань внаслідок травматичних подій пов'язана з ростом тривоги та симптомами посттравматичного стресового розладу [2]. Разом з тим, науковці [8] наголошують, що особистісний ріст після травматичних подій виникає саме в процесі переосмислення звичних переконань про світ та своє місце в ньому.

Аналіз останніх досліджень і публікацій. У сучасних доробках базові переконання привертають активну увагу науковців. В зарубіжній психології це дослідження: Д. Вайсе, Дж. Келли, Р. МакМаллин, А. Beck, M. Dutton, S. Epstein,E. K. Fletcher, R. JanoffBulman, K. Kaniasty, F. H. Norris, G. L. Skidmore. Серед російських науковців, варто зазначити О. Лазебная, М. А. Падун, Н. В. Тарабрина. Роль базових переконань як одного з факторів посттравматичної адаптації індивіда наводиться в ряді сучасних досліджень [3; 5; 7].

Виділення недосліджених раніше частин загальної проблеми. Незважаючи на значний інтерес науковців і психологів-практиків до соціально-психологічних проблем учасників антитерористичної операції, дослідження змін у структурі особистості, в тому числі і зміна базових переконань, після участі у бойових діях у вітчизняній науці $€$ досить новою галуззю теоретичного і практичного знання. Особливого значення дана інформація матиме в контексті порівняння індивідуально-психологічних характеристик комбатантів з особами, які не мають досвіду участі у бойових діях, позаяк ці дані можуть пояснити ті зміни, що відбуваються внаслідок впливу бойового стресу.

Постановка завдання. Метою публікації є висвітлення результатів емпіричного дослідження системи базових переконань учасників антитерористичної операції та їх порівняльний аналіз 3 контрольною групою.

Виклад основного матеріалу. Для реалізації наших завдань ми скористалися опитувальником Шкала базових переконань (World assumptions scale, WAS, адаптація М. А. Падун, А. В. Котельнікова) [4].

Методика складається з 37 пунктів-тверджень, які дозволяють оцінити виразність п'яти базових переконань про світ та себе: 1) «доброзичливість оточуючого світу» (переконання індивіда відносно можливості безпечно довіряти оточуючому світу); 2) «справедливість оточуючого світу» (переконання індивіда про те, що кожен отримує те, на що заслужив, тобто віра у справедливий розподіл добрих та поганих подій між людьми); 3) «образ Я» (базове переконання про цінність та значимість власного Я, переконання індивіда в тому, що він вартий поваги та любові); 4) «вдача» (переконання індивіда в тому, що він везуча людина); 5) «переконання про контроль» (впевненість людини в тому, що вона контролює те, що 3 нею відбувається). Респонденти оцінювали вірність тверджень по шестибальній шкалі від «Зовсім не згоден» до «Повністю згоден». Оцінка пунктів здійснювалась як по прямій, так і по інвертованій шкалі. Підрахунок показників здійснювався шляхом додавання балів по субшкалам характеристикам базових переконань.

В нашому дослідженні взяло участь 130 осіб, з них: 100 чоловіків, які брали участь в антитерористичній операції, віком від 21 до 50 років та 30 чоловіків контрольної групи, які не брали участь в бойових діях, віком від 22 до 48 років. Вибірка складалася з респондентів різного 
освітнього рівня, сімейного статусу, представників різних професій та соціальних груп. Учасники дослідження були відібрані з жителів міста Чернігова та Чернігівського району.

Опитування вибірки учасників антитерористичної операції проводилось на базі Центру психолого-соціальної допомоги «Ресурс» при первинному зверненні, перед складанням індивідуального плану психолого-соціальної допомоги.

На думку авторів когнітивна модель світу, що включає в себе набор імпліцитних уявлень індивіда про оточуючий світ, власне «Я», а також шляхи взаємодії між «Я» та світом представлена набором із п'яти субшкал:

базове переконання про доброзичливість/ворожість оточуючого світу відображає переконання індивіда відносно безпечної можливості довіряти оточуючому світу та відображається у субшкалі «Доброзичливість оточуючого світу»;

базове переконання про справедливість оточуючого світу характеризує переконання індивіда у принципах розподілу вдач та нещасть та містить дві категорії «Справедливість» та «Переконання про контроль»;

базове переконання про цінність та значимість власного «Я» відображаються у двох субшкалах «Вдача» та «Образ Я».

Зупинимось на результатах виразності кожної субшкали базових переконань (таб.1). Так, за показниками достовірності ( $\leq 0,05)$ рівень переконань у «Доброзичливості оточуючого світу» серед учасників антитерористичної операції $(\mathrm{M}=34,3)$ та контрольної групи $(\mathrm{M}=32,4)$ знаходиться в середніх значеннях $(31,9 \pm 5,1)$.

Складова «Справедливість» серед учасників антитерористичної операції $(\mathrm{M=24,7)}$ дещо вища, ніж у контрольної групи $(\mathrm{M}=23,9)$, проте також знаходиться в межах середніх значень $(22,6 \pm 3,6)$.

Показники за субшкалою «Образ Я» у вибірці учасників АТО $(\mathrm{M=32,4)}$ має високі значення, на відміну від контрольної групи (M=25,7), показники якої знаходяться в межах середніх значень $(25,2 \pm 3,2)$.

Показник за субшкалою «Вдача» серед вибірки учасників антитерористичної операції $(\mathrm{M}=28,1)$ дещо вищий за показники контрольної групи $(\mathrm{M}=27,4)$, проте обидва знаходяться в межах середніх значень $(27,3 \pm 3,3)$.

Складова «Переконання про контроль» серед учасників антитерористичної операції $(\mathrm{M}=33,2)$ має високі значенні, на відміну від контрольної групи $(M=27,8)$, значення якої знаходиться в межах середніх значень $(25,9 \pm 3,6)$.

Порівняльні показники за методикою «Шкала базових переконань»

Таблиця 1

\begin{tabular}{|l|r|c|c|}
\hline \multicolumn{1}{|c|}{ Складові життєстійкості } & кчасники АТО (1) & Mean & Середні значення \\
\hline Доброзичливість оточуючого світу & 1 & 34,3 & $31,9 \pm 5,1$ \\
\hline Справедливість & 2 & 32,4 & $22,6 \pm 3,6$ \\
\hline Образ «Я» & 1 & 24,7 & $25,2 \pm 3,2$ \\
\hline Вдача & 2 & 23,9 & $27,3 \pm 3,3$ \\
\hline Переконання про контроль & 2 & 25,7 & 2,4 \\
& 2 & 28,1 & $25,9 \pm 3,6$ \\
\hline
\end{tabular}

Враховуючи нерівність вибірки, для отримання інформації щодо розподілу показників за кожним критерієм нами був використаний хі-квадрат. Нижче представлено результати аналізу за цим показником.

Високий рівень за субшкалою «Доброзичливість оточуючого світу» виявлено у 1\% вибірки учасників антитерористичної операції та у жодного з вибірки контрольної групи. Середній рівень у $88 \%$ вибірки учасників АТО та 90\% вибірки контрольної групи. Низькі показники виразності цієї складової у 11\% вибірки учасників АТО та 10\% вибірки контрольної групи. Можемо припустити, що втрата відчуття дружелюбності та доброзичливості оточуючого світу є одним 3 головних джерел стресу для учасників бойових дій. 
Високі показники за субшкалою «Справедливість» виявлено у $64 \%$ вибірки учасників бойових дій та 46,6\% вибірки контрольної групи. Середній рівень у $29 \%$ вибірки учасників антитерористичної операції та 43,4\% вибірки контрольної групи. Низькі показники виявлено у 7\% вибірки учасників АТО та $10 \%$ вибірки контрольної групи. Припускаємо, що віра в справедливість та пов'язані з нею пошуки відповідей на запитання «Чому це сталося?», «Чому саме зі мною?», «Чим я заслужив це?», «Що мені робити далі?» сприяють глибокій рефлексії, переосмисленню свого життя, цілей, відносин з оточуючими і, як наслідок, особистісному росту.

Третя субшкала базових переконань «Образ Я» на високому рівні притаманна $57 \%$ вибірки учасників антитерористичної операції та $40 \%$ вибірки контрольної групи. Середній рівень $43 \%$ у вибірки учасників АТО та $60 \%$ у вибірки контрольної групи. Відсутність низьких показників за цією субшкалою свідчить про відсутність негативного сприйняття «образу Я», відсутність реакцій сорому та самозвинувачень. Високі показники за субшкалою «Образ Я» свідчать про те, що учасники антитерористичної операції усвідомлюють силу власної особистості, що вистояла в умовах війни, вони мають високу самооцінку та впевнені у власних можливостях.

Високі показники за субшкалою «Вдача» виявлено у $51 \%$ вибірки учасників бойових дій та 43,3\% вибірки контрольної групи. Середній рівень у 44\% вибірки учасників антитерористичної операції та 50\% вибірки контрольної групи. Низькі показники виявлено у 5\% вибірки учасників АТО та $6.6 \%$ вибірки контрольної групи. Участь у військових подіях несе загрозу для життя, в результаті чого серед комбатантів, зміцнюється переконання про вдачу. Більшість ветеранів вважають, що їм пощастило залишитись живими.

Високі показники за субшкалою «Переконання про контроль» виявлено у $61 \%$ вибірки учасників бойових дій та $30 \%$ вибірки контрольної групи. Середній рівень у $33 \%$ вибірки учасників антитерористичної операції та $63,3 \%$ вибірки контрольної групи. Низькі показники виявлено у 6\% вибірки учасників АТО та 6,7\% вибірки контрольної групи. Особи з високим та середнім рівнями виразності «Переконання про контроль» впевнені, що впливають на події в своєму житті, що боротьба впливає на результат, навіть якщо успіх не гарантовано. Опитані 3 низькими показниками невпевнені у власних силах, відчувають себе безпорадними.

Отже, отримані нами дані свідчать про те, що в колишніх комбатантів рівень базових переконань дещо вищий ніж у контрольної групи, і найбільше в них розвинуті такі показники базових переконань як «Образ Я» та «Переконання про контроль». Більшість опитаних ветеранів мають високу самооцінку, впевнені в тому, що людина здатна контролювати своє життя, вільно приймати рішення та втілювати їх у життя. Вони впевнені, що життя в їх руках та вони здатні ним керувати. Можемо стверджувати, що бойовий досвід в переважної частини учасників антитерористичної операції має конструктивний характер, що проявляється в усвідомленні сили власного Я, підвищенні цінності самого життя та знаходженні можливостей для самореалізації.

Здійснена перевірка на колеарність за допомогою теста Левіна, свідчить, що на рівні тенденції $(p \leq 0,1)$ були визначені такі значимі відмінності у двох групах: субшкалі базових переконань «Образ Я» $(0,031)$ та субшкалі «Переконання про контроль» $(0,015)$.

Висновки. Участь у бойових діях $є$ стресовою подією. Однак, стрес не $є$ перешкодою для виражених процесів посттравматичного росту, який пов'язаний з пошуком нових сфер для самореалізації, усвідомленням сили власної особистості, вірі в справедливість та переконання про контроль. Військовий досвід та його наслідки мають бути інтегровані в цілісну картину світу, ідентичність та систему соціальних зв'язків комбатанта.

До соціально-психологічних факторів, що сприяють успішній інтеграції комбатантів у мирне життя можемо віднести: позитивне уявлення особи про себе як суб'єкта травматичного досвіду; широта соціальних зв'язків за рахунок включення особи в різні соціальні групи; якість соціальнопсихологічної підтримки, що сприяє інтеграції травматичного досвіду в цілісну картину власного досвіду.

Результати нашого тестування дозволяють нам дійти висновку про те, що у переважної більшості досліджених нами комбатантів базові переконання мають досить високий рівень, особливо за показниками «Образ Я» та «Переконання про контроль». Це може пояснюватися передусім тим, що участь у бойових діях фрормує у людини високий адаптаційний потенціал та стійкість до стресових обставин, готовність приймати складні обставини та «переробляти» їх у 
важливий життєвий досвід. Це підвищує їх самооцінку, розвиває відповідальність за власне життя, а також сприяє позитивному сприйняттю себе та своєї ролі у власному життєбудуванні.

Відтак, розвиток соціально-психологічних послуг для означеної категорії осіб має відбуватися не стільки у руслі психотерапевтичної підтримки, а через наснаження, формування віри у власні сили та можливості, покращення відносин з оточуючими людьми, визначення цінності досвіду комбатантів для суспільства в цілому та кожної конкретної громади зокрема.

Перспективу подальших досліджень вбачаємо у вивченні інших соціально-психологічних характеристик учасників антитерористичної операції. Зокрема, представляє інтерес дослідження особливостей побудови їх життєвої перспективи, стилів саморегуляції поведінки та типів рефлексії, позаяк ці дані можуть вплинути на зміст психореабілітаційних послуг і заходів.

\section{Література}

1. Державна служба України у справах ветеранів війни та учасників антитерористичної операції. Офріційна сторінка [Електронний ресурс]. - Режим доступу http://dsvv.gov.ua/dostup-do-publichnoji-informatsiji/informatsiyaschodo-nadannya-statusu-uchasnyka-bojovyh-dij.html.

2. Падун, М. А. Психическая травма и картина мира: теория, эмпирия, практика / М. А. Падун, А. В. Котельникова. - М., 2012. -206 c.

3. Тарабрина, Н. В. Особенности базисных убеждений у лиц, переживших травматический стресс : дис. ... канд. психол. наук : 19.00.04 / Н. В. Тарабрина. - Москва, 2003 - 159 с.

4. Падун, М. А. Модификация методики исследования базисных убеждений личности Р. Янофф-Бульман / М.А. Падун, А. В. Котельникова // Психологический журнал. - 2008. - Том 29, № 4. - С. 98-107.

5. Janoff-Bulman, R. Assumptive worlds and the stress of traumatic events: Application of the schema construct / Janoff-Bulman R. // Social Cognition - 1989. - № 7. - P.113-136.

6. Janoff-Bulman, R. Posttraumatic growth: Three explanatory models / R. Janoff-Bulman // Psychological Inquiry. - 2004. - № 15. - P. 30-34.

7. Mikkelsen, E. G. Basic assumptions and symptoms of post-traumatic stress among victims of bullying at work / E. G. Mikkelsen, S. Einarsen // European Journal of Work and Organization Psychology. - 2002. - 11 (1). - P. $87-111$.

8. Tedeschi, R. G. Posttraumatic Growth: Conceptual Foundations and Empirical Evidence / R. G. Tedeschi, L. G. Calhoun // Psychological Inquiry. - 2004. - Vol. 15. - iss. 1. - P. 1 - 18.

\section{References}

1. Informatsiia shchodo nadannia statusu uchasnyka boiovykh dii [Information on granting the status of participant in military operations]. dsvv.gov.ua. Retrieved from http://dsvv.gov.ua/dostup-do-publichnoji-informatsiji/informatsiya-schodonadannya-statusu-uchasnyka-bojovyh-dij.html [in Ukrainian].

2. Padun, M. A., Kotelnikova, A. V. (2012). Psikhicheskaya travma i kartina mira: teoriya, empiriya, praktika [Psychic trauma and picture of the world: theory, empiricism, practice]. Moscow: Ros. akad. nauk, In-t psikhologii [in Russian].

3. Tarabrina, N. V. (2003). Osobennosti bazisnykh ubezhdeniy u lits, perezhivshikh travmaticheskiy stress [Features of basic beliefs in persons who have experienced traumatic stress]. Candidate's thesis. Moscow [in Russian].

4. Padun, M. A., Kotelnikova, A. V. (2008). Modifikatsiya metodiki issledovaniya bazisnykh ubezhdeniy lichnosti R. Yanoff-Bulman [Modification of the methodology for the study of basic convictions of the personality R. Yanoff-Bulman]. Psikhologicheskiy zhurnal - Psychological Journal, 29(4), 98-107 [in Russian].

5. Janoff-Bulman, R. (1989). Assumptive worlds and the stress of traumatic events: Application of the schema construct. Social Cognition, 7, 113-136 [in English].

6. Janoff-Bulman, R. (2004). Posttraumatic growth: Three explanatory models. Psychological Inquiry, 15, 30-34 [in English].

7. Mikkelsen, E. G., Einarsen, S. (2002). Basic assumptions and symptoms of post-traumatic stress among victims of bullying at work. European Journal of Work and Organization Psychology, 11(1), 87-111 [in English].

8. Tedeschi, R. G., Calhoun, L. G. (2004). Posttraumatic Growth: Conceptual Foundations and Empirical Evidence. Psychological Inquiry, 15 (1), 1-18 [in English].

Надійшла 20.04.2019

Бібліографічний опис для цитування :

Мульована, Л. І. Аналіз результатів емпіричного дослідження базових переконань учасників антитерористичної операції / Л. І. Мульована, Т. С. Острянко // Проблеми соціальної роботи: філософія, психологія, соціологія. - 2019. - № 1 (13). - C. $65-70$. 